九州大学学術情報リポジトリ

Kyushu University Institutional Repository

Effects of Different Types of Litters and Fertilizer Application on Growth and Productivity of Maize (Zea mays L. var. Across 86 Pool 16) in Senegal

Sarr, Papa Saliou

Center for African Area Studies, Kyoto University

Diouf, Macoumba

Centre d'Etude Régional pour l'Amélioration de l'Adaptation à la Sécheresse(CERAAS) | CERAAS

Diallo, Mariama Dalanda

UFR Sciences Agronomiques, Aquaculture et de Technologie Alimentaire(S2ATA), Université Gaston Berger de Saint Louis

Ndiaye, Saliou

Ecole Nationale Supérieure d'Agriculture(ENSA) | Ecole Nationale Supérieure d'Agricul ture (ENSA)

他

https://doi.org/10.5109/27356

出版情報：九州大学大学院農学研究院紀要. 58 (2)，pp.259-267，2013-09. Faculty of Agriculture， Kyushu University

バージョン :

権利関係: 


\title{
Effects of Different Types of Litters and Fertilizer Application on Growth and Productivity of Maize (Zea mays L. var. Across 86 Pool 16) in Senegal
}

\author{
Papa Saliou SARR ${ }^{1 *}$, Macoumba DIOUF ${ }^{5}$, Mariama Dalanda DIALLO $^{4}$, Saliou NDIAYE $^{3}$, \\ Rouguiyatou DIA ${ }^{3}$, Aliou GUISSE ${ }^{2}$ and Takeo YAMAKAWA
}

Laboratory of Plant Nutrition, Division of Molecular Biosciences,

Department of Bioscience and Biotechnology, Faculty of Agriculture, Kyushu University, Fukuoka 812-8581, Japan

(Received April 25, 2013 and accepted May 9, 2013)

\begin{abstract}
This study aimed to characterize the effects of the application of different types of litters and fertilizer on the growth and productivity of maize (Zea mays L. var.) in Senegal. A split plot experiment was conducted in a low fertile soil at Thiès. Three factors corresponded to: inorganic fertilizer as urea at two levels $(0,2)$, insecticide as fipronil at two levels $(0,2)$ and litter type at 5 levels $(\mathrm{D}, \mathrm{A}, \mathrm{B}, \mathrm{E}, \mathrm{F})$. Zero $(0)$ represented the controls without fertilizer, insecticide or litter application. Two (2) corresponded to an application of $71.4 \mathrm{~kg} \mathrm{ha}^{-1} \mathrm{~N}$ fertilizer, and $7.5 \mathrm{~L} \mathrm{ha}^{-1}$ insecticide, both sequentially applied 3 times during the trial. D, A, B, E, F corresponded to the control, $5.7 \mathrm{t} \mathrm{ha}^{-1}$ of Andropogon gayanus Kunth, Casuarina equisetifolia (Forssk), Pennisetum glaucum (L.) R. Br. and Faidherbia albida (Chev.) litters, respectively, applied 73 days before sowing. This gave a total of 20 experimental units with 3 replications each. With no inorganic or insecticide application, the effect on growth parameters (plant height, medium collar diameter, number of leaves per plant) was not significantly different among the different applied litters. Litter application positively affected the growth parameters compared to the control. F. albida litter increased the quantic maximal output of the photochemical activity by $6 \%$ and the energy use efficiency by $26 \%$, compared to the other litter types. At harvest, litters of $F$. albida, C. equisetifolia and P. glaucum increased grain yields by $94.3 \%$ over the control. The addition of inorganic fertilizer and/or insecticide improved the stem collar diameter and plant height and grain yield. In conclusion, the incorporation of locally available litters (more specifically that of the leguminous plants $F$. albida and C. equisetifolia) and their combination with inorganic $\mathrm{N}$ fertilizer and insecticide are good alternatives to increase maize production in tropical croplands.
\end{abstract}

Key words: litter, photochemistry, growth, productivity, corn

\section{INTRODUCTION}

Achieving food security in its totality continues to be a challenge not only for developing nations, but also for the developed world. In the 1996 Rome Declaration on World Food Security, food security is defined as: food that is available at all times, to which all persons have means of access; that is nutritionally adequate in terms of quantity, quality, and variety; and is acceptable within a given culture (Madeley, 2002). Therefore, food insecurity is not simply a failure of agriculture to produce sufficient food at the national level, but instead a failure of livelihoods to guarantee access to sufficient food at the household level. Thus, availability, access, and affordability are all elements of food security. Food security is affected by a complexity of factors. The root cause in developing

Center for African Area Studies, Kyoto University, 46 Shimoadachi-cho, Sakyo-ku, Yoshida 606-8581, Kyoto-Japan

Université Cheikh Anta Diop, Faculté des Sciences et Techniques/Département de Biologie Végétale, BP 5005 Dakar, Sénégal

Ecole Nationale Supérieure d'Agriculture (ENSA), BP A 296 Thiès, Sénégal

${ }^{4}$ UFR Sciences Agronomiques, Aquaculture et de Technologie Alimentaire (S2ATA), Université Gaston Berger de Saint Louis, BP 234, Saint-Louis, Sénégal

Centre d'Etude Régional pour l'Amélioration de l'Adaptation à la Sécheresse (CERAAS), BP 3320 Thiès-Escale, Thiès, Sénégal

* Corresponding author (E-mail: sarr.papa@voila.fr) countries, Africa in general and Sub-Saharan Africa in particular, is the inability of people to gain access to food due to poverty (IAC, 2004). The major challenge for Africa in terms of food security is its underdeveloped agricultural sector that is characterized by over-reliance on primary agriculture, low soil fertility, minimal use of external farm inputs, environmental degradation, significant food crop loss both pre- and post-harvest, minimal value addition and product differentiation, and inadequate food storage and preservation that results in significant commodity price fluctuation. In Senegal, as in all other West-African countries, the food situation is far from being satisfactory, and more than $32 \%$ of households live under the poverty line (Daps, 1990). Ninety five percent of the food in Sub-Saharan Africa is grown under rain fed agriculture (IAC, 2004). Hence, food production is vulnerable to adverse weather conditions. Since the 70's, agriculture in the Sahelian area has been characterized by erratic rainfalls (Davis-Carter, 1989). There is an overall decline in farm input investment including fertilizers, seeds, and the adoption of technology. The soils continue to degrade leading to the reduction of farm productivity. Other factors that negatively affect agriculture in Africa include the decline in the use and length of fallow periods, the expansion of agricultural production into marginal and fragile areas, the removal of vegetation through over grazing, the rapid population growth leading to land pressure, the limited access to agriculturerelated technical assistance, and the lack of knowledge 
about profitable soil fertility management practices leading to expansion into less-favourable lands. Food crops draw more nutrient elements from soils than they return in the year. Along this line, Badiane (1993) reported that a decrease in soil fertility in the tropical area of Senegal is related to low nutrient replenishment, depleting the soil of organic matter and mineral elements such as $\mathrm{N}$ and $\mathrm{P}$. The loss of productivity of soils in Sub-Saharan Africa is often related to the decrease of soil organic matter and nutrient status. It is well known that the amendment of plant residues can improve soil's nutrient content, physical properties and biological activity, as well as crop performance (Aggangan et al., 1999; Caravaca, 2002; Roldan, 1996). Application of organic inputs, such as crop residues, has to be considered for the development of sustainable agricultural systems (Quintana, 1988).

In order to reverse the tendency of food importation dominated by rice, the Senegalese government has implemented a follow-up policy of cereal production through the Local Cereal Promotion Programme (Broutin and Sokona, 1999). This programme in part, encourages the consumption of locally produced cereals in order to promote growth in production. Apart from millet, sorghum, and rice; which are the most cultivated cereals, maize constitutes one of the staple foods in the central and southern parts where it is well cultivated. This plant has high potassium, nitrogen and phosphorus requirements (Anon, 1997), and thus requires a good fertile soil. Taking into account the management of land fertility in agricultural practices is one of the most appropriate strategies against land degradation in most cereal-producing developing countries. Hence, it is necessary to broaden the knowledge of options for preserving the soil's organic material in an environment characterized by a low availability of manures and a high cost of fertilizers (Scoones, 1990). Besides, for many decades efforts have been put into on the recovery of the harvest waste and plant materials, directly or indirectly via animals, to improve the organic manuring practice (Hamon, 1968; 1972). Murwira and Kirchmann (1993) indicated that nutrient use efficiency may increase through the combination of manure and fertilizer.

The effect of nutrient sources, such as litters of highly available weeds and multi-purpose tree litters, on soil quality and crop production remains poorly studied in Senegal. However, litters of the tree species such as Casuarina equisetifolia (exotic), Faidherbia albida (native); herbaceous species (Andropogon gayanus), and cultivated crops (Pennisetum glaucum) are highly available in the agro-ecosystems. This study was designed to investigate the effect of the application of these species' litters on the growth and production of maize (Across Pool 16 variety). It also aimed to determine to which extend the combination of these litters with organic fertilizer and insecticide could affect the growth and the production of maize. As reported by Diallo et al. (2005), the C/N ratios of Andropogon gayanus, Casuarina equisetifolia, Faidherbia albida and Pennisetum glaucum litters are 51, 35, 21.4, and 50, respectively.

\section{MATERIALS AND METHODS}

\section{Experimental site}

This study was conducted at the Centre of Agricultural Technical Application (CATA) of the Ecole Nationale Superieure d'Agriculture (ENSA) in Thiès, located in South-Central Senegal (14 $42^{\prime} \mathrm{N}$ and $16^{\circ} 57^{\prime} \mathrm{W}$ ). The site is set up on a dead-beat tropical ferruginous land of a "Dek-dior" type, with a high soil $\mathrm{C} / \mathrm{N}$ ratio ranging from 13 to 18.35 in the first $30 \mathrm{~cm}$ soil depth. The organic material rate $(0.62-1.26 \%)$ in the top layer of the experimental site is satisfactory enough for a sandy-clayey soil. Delville (1996) determined a range of 0.6 to $1 \%$ organic material for sandy soils. The region belongs to a cover zone between the Sudano-Sahelian savannas and the Sahelian formations (MEPN, 1997) located under the dune system of the coastal sector. The plant species encountered in the region are mainly Adansonia digitata, Faidherbia albida, Acacia raddiana, Acacia seyal, Balanites aegyptiaca, Borassus aethiopium and Acacia ataxacantha. The climate of the region is characterized by a short wet season (JuneOctober) and a long dry season (October-June), with erratic rainfalls. During the 2002 rainy season, the amount of accumulated rainfall $(243.5 \mathrm{~mm})$ was less than the average rain of the previous ten years $(425 \mathrm{~mm})$. The month of July was particularly drier with only two rains in a 20 day interval. To fill the water deficit, extra irrigations (118.5 mm) were carried out to give a total of $362 \mathrm{~mm}$ for this cropping season (Fig. 1).

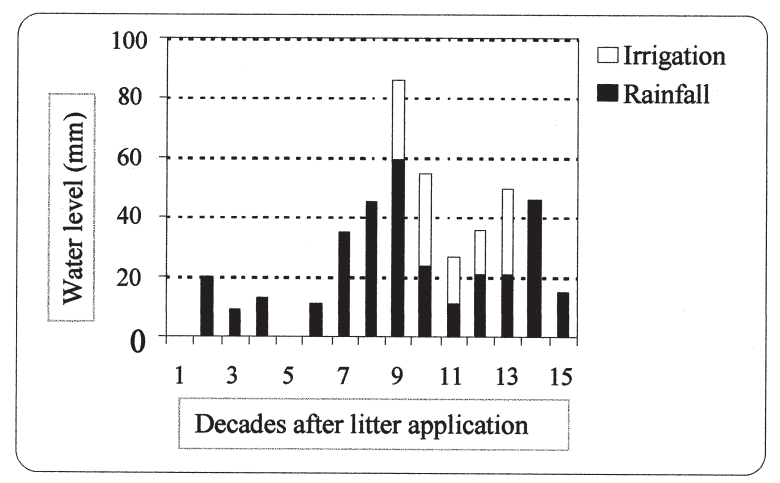

Fig. 1. Decade distribution of rains and extra irrigation during the cultivation period.

\section{Plant material}

This study was carried out using the maize (Zea mays) genotype Across Pool 16 issued from the ISRA (Institut Senegalais de Recherches Agricoles) series (Ndiaye, 1994). The basic genetic material, introduced in Senegal in 1986, originated from IITA (International Institute of Tropical Agriculture, Ibadan, Nigeria), and later gave the Across 86 Pool 16 variety. The plant matures between 75 to 80 days, with the female blossoming appearing at 48 days. At maturity, the grains appear a white colour. It is a plant material recommended for 
the South zone of the groundnut Basin (Médina Sabakh, Missirah Walo, Porokhane and Keur Samba Guèye villages) and villages in the Thiès region, after multiannual tests in the real environment and in a research station.

\section{Experimental design}

Three factors (litter type, inorganic fertilizer, and insecticide) were tested in a split plot design. The litter type factor included the 5 levels D, A, B, E, F; where "D" corresponded to a control without mulching, and "A, B, E, F" corresponded to $5.7 \mathrm{t} \mathrm{ha}^{-1}$ of Andropogon gayanus Kunth, Casuarina equisetifolia (Forssk), Pennisetum glaucum (L.) R. Br. and Faidherbia albida (Chev.) litters, respectively. These litters were selected because they are abundantly found in the area. The inorganic fertilizer and insecticide factors corresponded to the application of urea and fipronil at 2 levels $(0,2)$ each. Zero (0) represented controls without urea or fipronil application, while two (2) corresponded to a total application of $71.4 \mathrm{~kg} \mathrm{ha}^{-1}$ of fertilizer and $7.5 \mathrm{~L} \mathrm{ha}^{-1}$ of insecticide; both sequentially supplemented 3 times during the course of the experimentation. The combination of the three factors (litter $\times$ fertilizer $\times$ insecticide) with their respective levels $\left(\mathrm{x}_{\mathrm{i}}\right)$ gave a total of 20 treatments. Such combination resulted to the following: 5 treatments corresponding to the 5 levels of litter factor, when we consider the zero levels of fertilizer and insecticide (D, A, B, E, and F); 5 treatments corresponding to the combination of $7.5 \mathrm{~L} \mathrm{ha}^{-1}$ insecticide with the 5 litter levels (NOF2, ANOF2, BNOF2, ENOF2, and FNOF2); 5 treatments corresponding to the combination of $71.4 \mathrm{~kg}$ $\mathrm{ha}^{-1}$ of fertilizer with the 5 litter levels (N2F0, AN2F0, $\mathrm{BN} 2 \mathrm{~F} 0, \mathrm{EN} 2 \mathrm{~F} 0$, and $\mathrm{FN} 2 \mathrm{~F} 0$ ); and the remaining 5 treatments including litter, fertilizer, and insecticide (N2F2, AN2F2, BN2F2, EN2F2, and FN2F2). "D" treatment was without litter, fertilizer, or insecticide and was equivalent to "NOF0". "NOF2" corresponded to the only presence of fipronil (insecticide), "N2F0" was the only application of nitrogen (fertilizer), and "N2F2" corresponded to the treatment with only nitrogen and fipronil. These 20 treatments were replicated 3 times each, giving a total of 60 experimental units (plots). Plot size was $7 \mathrm{~m}^{2}$ with 4 lines of $3.5 \mathrm{~m}$. There was $50 \mathrm{~cm}$ spacing between lines and $70 \mathrm{~cm}$ between hills in a line (total 20 hills). A space of $1.5 \mathrm{~m}$ and $4 \mathrm{~m}$ was left between plots and between the blocks, respectively.

The experimental area was primarily ploughed dry at $10 \mathrm{~cm}$ depth, using a mechanical ploughing machine. Litters were applied at $4 \mathrm{~kg}$ per plot $\left(5.7 \mathrm{t} \mathrm{ha}^{-1}\right) 73$ days before the sowing (to allow for decomposition before the first rains). Four previously thiramius-treated $\left(1 \mathrm{~g} \mathrm{~kg}^{-1}\right.$ dose) maize grains were sown per hill on August 14 after a rain of $24 \mathrm{~mm}$. At the planting period, $\mathrm{P}$ and $\mathrm{K}$ fertilizers were applied in the whole area at $57 \mathrm{~kg} \mathrm{ha}^{-1}$ each as a starter, to facilitate early seedling growth. Nitrogen as urea was applied at the rate of $71.4 \mathrm{~kg} \mathrm{ha}^{-1}$ in total on three occasions (at sowing, at $32^{\text {th }}$ and $64^{\text {th }}$ days after the sowing -DAS-). As for the fipronil (insecticide), a total dose of $7.5 \mathrm{~L} \mathrm{ha}^{-1}$ was sprayed (a $1.5 \mathrm{~L} \mathrm{ha}^{-1}$ application during mulching and two applications of $3 \mathrm{~L} \mathrm{ha}^{-1} 15$ days apart). Cultivation and weeding were carried out as needed during the developing cycle.

\section{Studied parameters}

Apart from leaf area index, three plants were randomly selected from each plot, and the following measures were carried out once a week up to maturity. At harvest, the central 9 plants $\left(3.15 \mathrm{~m}^{2}\right)$ out of the total 20 plants of the plot were considered to estimate the yield components.

Soil humidity

The soil humidity was measured using the gravimetrical method. Soil samples were taken at a 10, 30, and $60 \mathrm{~cm}$ depth in each plot and at each sampling period. The fresh weight $(\mathrm{FW})$ of the samples was determined using a METTLER precision scale. After oven drying at $105^{\circ} \mathrm{C}$ for 48 hours, the dry weigh (DW) was recorded. Thus, the soil humidity weight (Hw) in a plot was calculated from the equation: $\mathrm{Hw}(\%)=[(\mathrm{FW}-\mathrm{DW}) / \mathrm{DW}] \times 100$, and the mean value of each treatment was calculated.

Leaf area index (LAI)

The leaf area index (LAI) was measured weekly between $9 \mathrm{~h} 30 \mathrm{mn}$ and $10 \mathrm{~h} 30 \mathrm{mn}$, with a surface analyzer of a Licor model LAI 2000 type 2000 (Licor, Nebraska, USA). In each plot, one measure was taken above and four below (diagonally between two lines) the same canopy, with 2 repetitions.

Physiological and agro-morphological parameters

The physiological measures mainly concerned the chlorophyll fluorescence, measured using a fluorimeter of Hansatech model PEA (Plant Efficiency Analyser, Hansatech Instruments Ltd, King's Lynn, England) type. It allows one to determine the photochemical activity of the plants, which is closely related to the photosynthetic activity. During plant growth, agro-morphological parameters such as the number of leaves per plant (NLP), the plant height $(\mathrm{PH})$ and the plant medium collar diameter (MCD) were recorded. At harvest (77 DAS), fresh plant material was first dried in the laboratory in open-air for two weeks, and later under shelter for one week. The maize ears at harvest were left to dry for 21 days. The different agronomic parameters determined included the number of ears per plant (NEP), the number of grains per ear (NGE), the total grains yield (GY), and the weight of 1000 grains (WTG).

\section{Statistical analysis}

Analysis of variance (ANOVA) and discriminating factoring (AFD) were performed using STATITCF (Version 5, ITCF) software for all the determined agronomic parameters. The Newman-Keuls test was used for means comparison.

\section{RESULTS}

\section{Monitoring of the soil humidity}

The evolution of the soil humidity balance was monitored along the cultivation period (Fig. 2). The results of the analysis of variance didn't show any significant dif- 


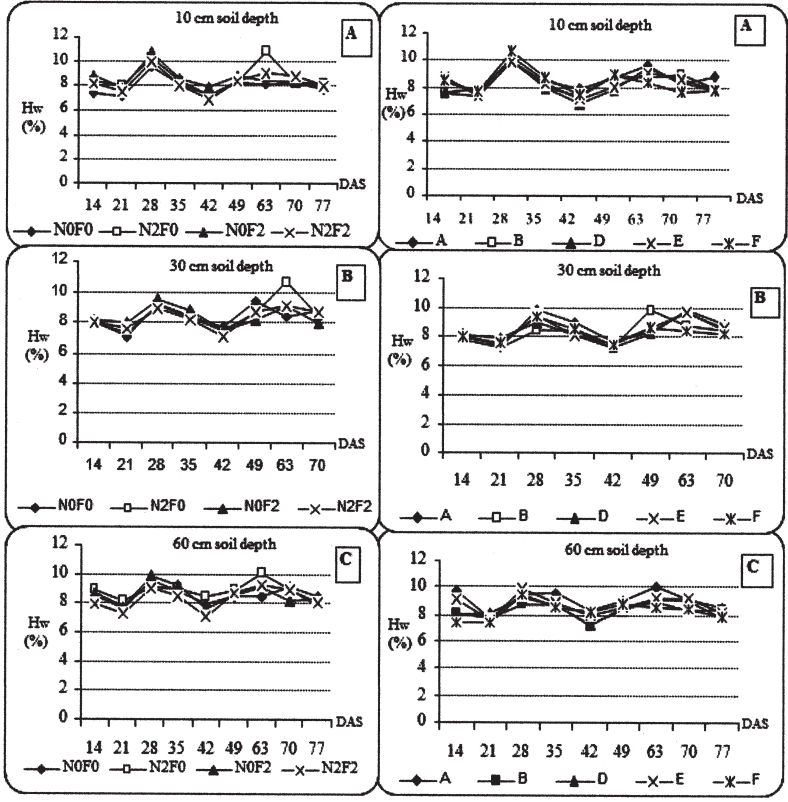

Fig. 2. Evolution of the humidity weight (Hp) balance at 10, 30 and $60 \mathrm{~cm}$ soil depths in relation with the different treatments

Values for each soil depth at each sampling period are means of 3 replicates plots. Results from "fertilizer $\times$ insecticide" interaction and litter types are shown. NOF0=no nitrogen and fipronil; $\mathrm{N} 2 \mathrm{~F} 0=$ only nitrogen; N0F2=only fipronil; N2F2=combination of nitrogen and fipronil; $\mathrm{A}=$ Andropogon gayanus; $\mathrm{B}=$ Casuarina equisetifolia; $\mathrm{D}=$ Control $; \mathrm{E}=$ Pennisetum glaucum $; \mathrm{F}=$ Faidherbia albida; $\mathrm{Hp}=$ ponderal humidity; DAS=days after sowing.

ference between the three soil depths of 10, 30, and $60 \mathrm{~cm}$, neither for the fertilizer $\times$ insecticide combination (except at $63^{\text {th }}$ DAS for the $10 \mathrm{~cm}$ and $30 \mathrm{~cm}$ depths where the treatment with only urea application showed higher soil humidity), nor for the different litter type treatments (except at $14^{\text {th }}$ DAS for the $60 \mathrm{~cm}$ depth where soil humidity in the control without mulching was higher, followed by the Pennisetum glaucum treatment). Correlating to Fig. $1,14^{\text {th }}$ and $16^{\text {th }}$ DAS correspond to the $9^{\text {th }}$ and $14^{\text {th }}$ decades after litter application with the highest amounts of rain (60 $\mathrm{mm}$ and $44 \mathrm{~mm}$, respectively). Without mulching, water infiltration is faster and accumulates in deeper depths, while the incorporation of plant debris contributes to the maintenance of surface soil humidity, which is beneficial for plant growth.

\section{Physiological and agronomic outputs}

The analysis of variance made on the growth parameters didn't reveal any significant difference in the "litter $\times$ fertilizer $\times$ insecticide" interaction (Table 1 ). However, significant differences were observed when the litter treatment was separated from the "fertilizer $\times$ insecticide" combination. Therefore, results of the combination of the 3 factors are not reported. The plant height (PH) was only significantly different between treatments in the "fertilizer $\times$ insecticide" interaction. The evolution of $\mathrm{PH}$ (Fig. 3) follows the same trend for all treatments. It is characterized by a slow growing phase $(25 \mathrm{~cm}$ height at the $35^{\text {th }} \mathrm{DAS}$ ), followed by a fast growing period reaching the maximum height at the $63^{\text {th }}$ DAS. At the maturing phase, extending from the $63^{\text {th }}$ DAS up to the $76^{\text {th }}$ DAS, the plant growth stopped and the yellowing of leaves increased. During the growing period between 40 to 50 DAS, the plant height was significantly lower in the control without fertilizer and insecticide compared to the other treatments (Fig. 3A). The plant height was also lower in the control without mulching but it was not significantly different with the other litter types. At $70^{\text {th }}$ DAS, although not significant, the plant height was higher in the presence of both urea and fipronil compared to the presence of the two components taken separately. Similarly, when we consider the litter types, the Faidherbia albida litter led to a greater plant height, while the Pennisetum glaucum litter led to the poorest growth (Fig. 3B).

Table 1. Results of the ANOVA (test Student Newman-Keuls $p=0.05$ ) on the variables related to the growth and productivity

\begin{tabular}{|c|c|c|c|c|c|c|}
\hline \multirow{2}{*}{ Parameters } & \multicolumn{2}{|c|}{ Fertilizer $\times$ Insecticide $(\mathrm{F} \times \mathrm{I})$} & \multicolumn{2}{|c|}{ Litter (L) } & \multicolumn{2}{|c|}{ Interaction $\mathrm{L} \times \mathrm{F} \times \mathrm{I}$} \\
\hline & Probability & F-value & Probability & F-value & Probability & F-value \\
\hline PHmax & 0.0003 & $* * *$ & 0.1482 & ns & 0.6081 & ns \\
\hline NLPmax & 0.9165 & ns & 0.5893 & ns & 0.3509 & ns \\
\hline MCDmax & 0.0018 & $* *$ & 0.1843 & ns & 0.4231 & ns \\
\hline NEP & 0.0373 & $*$ & 0.416 & ns & 0.5985 & ns \\
\hline NGE & 0.4586 & ns & 0.0104 & $*$ & 0.1583 & ns \\
\hline LAImax & 0.6147 & ns & 0.668 & ns & 0.3693 & ns \\
\hline WTG & 0.0387 & $*$ & 0.9629 & ns & 0.8806 & ns \\
\hline GY & 0.045 & $*$ & 0.0034 & $* *$ & 0.102 & ns \\
\hline BY & 0.0022 & $* *$ & 0.4912 & ns & 0.6089 & ns \\
\hline
\end{tabular}

In bold, probabilities for the significant tests.*,** and $* * *=$ significant test at 5,1 and $0.1 \%$; ns=not significance at 5\%. PHmax=maximum height of the plant. NLPmax=maximum number of leaves per plant; MCDmax=maximum medium collar diameter; $\mathrm{NEP}=$ number of ears per harvesting area; LAImax=maximum leaf area index; WTG=weight of thousand grains; NGE=number of grains per ear; GY=grains yields; BY=biomass yields 


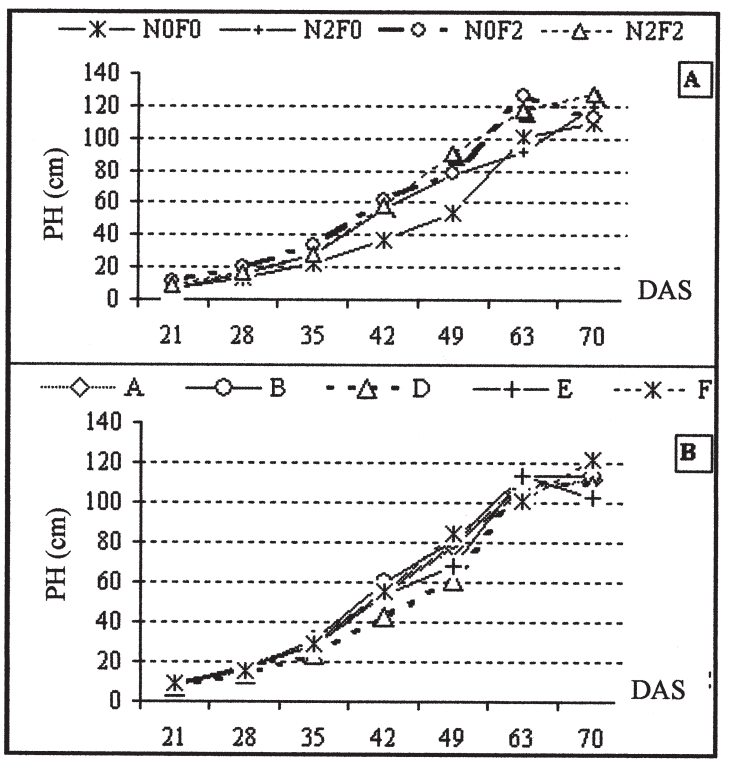

Fig. 3. Plant Height evolution during the cultivation period as affected by the "fertilizer $\times$ insecticide" interaction (A) and litter types (B)

Results at each sampling period are means from 3 replicates plots per treatment. $\mathrm{PH}=\mathrm{Plant}$ height $\mathrm{NOF} 0=$ no nitrogen and fipronil; N2F0=only nitrogen; N0F2=only fipronil; $\mathrm{N} 2 \mathrm{~F} 2=$ combination of nitrogen and fipronil; $\mathrm{A}=$ Andropogon gayanus; $\mathrm{B}=$ Casuarina equisetifolia; $\mathrm{D}=$ Control; $\mathrm{E}=$ Pennisetum glaucum $; \mathrm{F}=$ Faidherbia albida; DAS=days after sowing

The ANOVA revealed significantly different data at $1 \%$ level for the medium collar diameter (MCD) when we consider the fertilizer $\times$ insecticide interaction (Table 1). Figure 4 shows the evolution of the MCD of the variety with the fertilizer and insecticide combination (Fig. 4A), and litter type (Fig. 4B). Figure 4A reveals a significantly smaller MCD of the control plant (no fertilizer, no insecticide), especially at the $42^{\text {th }}$ and $49^{\text {th }}$ DAS, compared to when fertilizer and/or insecticide is applied. The control treatment without any litter application also gave smaller MCD but the difference was not significant (Fig. 4B) with the other litter types; by contrast the Faidherbia albida litter gave a relatively larger MCD. At 70th DAS, indifferent to the type of litter to be considered, the treatment with urea application gave significantly larger MCD $(1.5 \mathrm{~cm})$, and the control without fertilizer and insecticide had the smallest MCD $(0.67 \mathrm{~cm})$. A positive correlation was observed between plant height, MCD, and time, in that at given periods plants with a larger MCD had the highest height, which was affected by the applied treatment.

The leaf area index (LAI) was measured to follow the evolution of the canopy during the experimentation period (Fig. 5). It appears that the LAI shows the same trend for all studied factors during the cycle, and there was no significant difference among them (Table 1). The index increased to reach the maximal value of 0.78 at the $63^{\text {th }}$ DAS (Fig. 5A, 5B). This period corresponded to the $14^{\text {th }}$ decade after litter application, characterized by optimal soil humidity. Afterwards, the index got reduced until reaching the $71^{\text {th }}$ DAS with an average value of 0.71 .

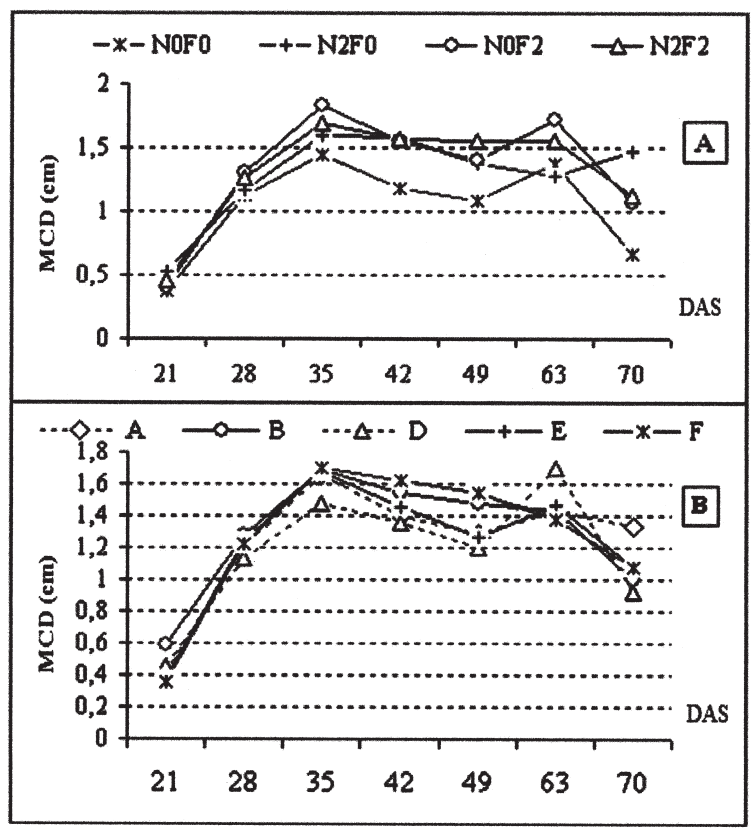

Fig. 4. Stem diameter evolution during the cultivation period as affected by the "fertilizer $\times$ insecticide" interaction (A) and litter types (B)

Results at each sampling period are means from 3 replicates plots per treatment. MCD=medium coller diameter, $\mathrm{N} 0 \mathrm{~F} 0=$ no nitrogen and fipronil; $\mathrm{N} 2 \mathrm{~F} 0=$ only nitrogen; N0F2=only fipronil; N2F2=combination of nitrogen and fipronil; $\mathrm{A}=$ Andropogon gayanus; $\mathrm{B}=$ Casuarina equisetifolia; $\mathrm{D}=\mathrm{Control;} \mathrm{E}=$ Pennisetum glaucum; $\mathrm{F}=$ Faidherbia albida; DAS=days after sowing

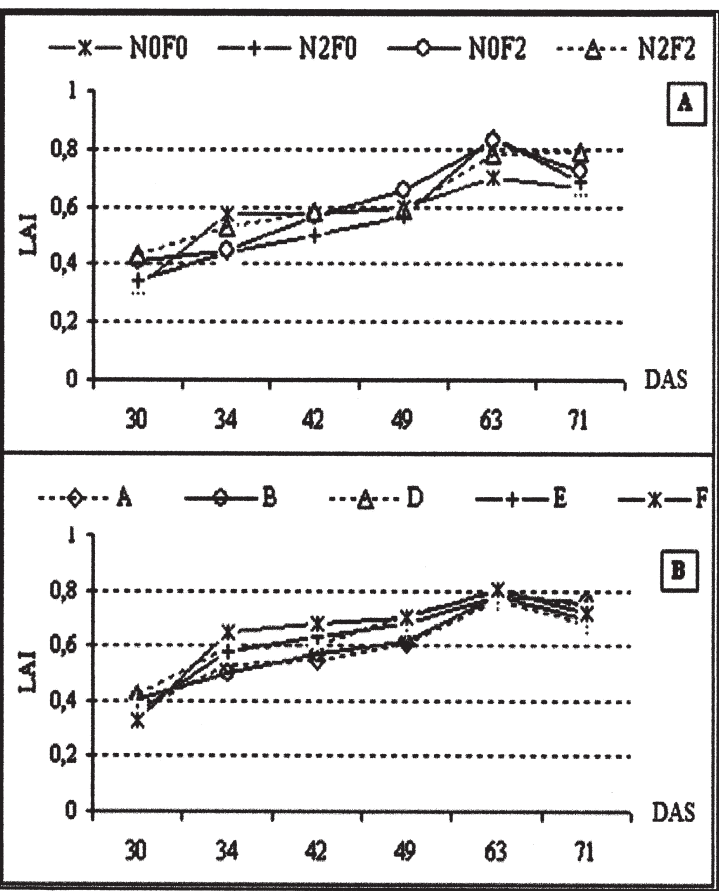

Fig. 5. Evolution of leaf area index during the cultivation period as affected by the "fertilizer $\times$ insecticide" interaction (A) and litter types (B)

Results at each sampling period are means from 3 replicates plots per treatment. LAI $=$ Leaf area index; $\mathrm{N} 0 \mathrm{~F} 0=$ no nitrogen and fipronil; N2F0=only nitrogen; N0F2=only fipronil; N2F2=combination of nitrogen and fipronil; $\mathrm{A}=$ Andropogon gayanus; $\mathrm{B}=$ Casuarina equisetifolia; $\mathrm{D}=$ control; $\mathrm{E}=$ Pennisetum glaucum; $\mathrm{F}=$ Faidherbia albida; DAS=days after sowing 


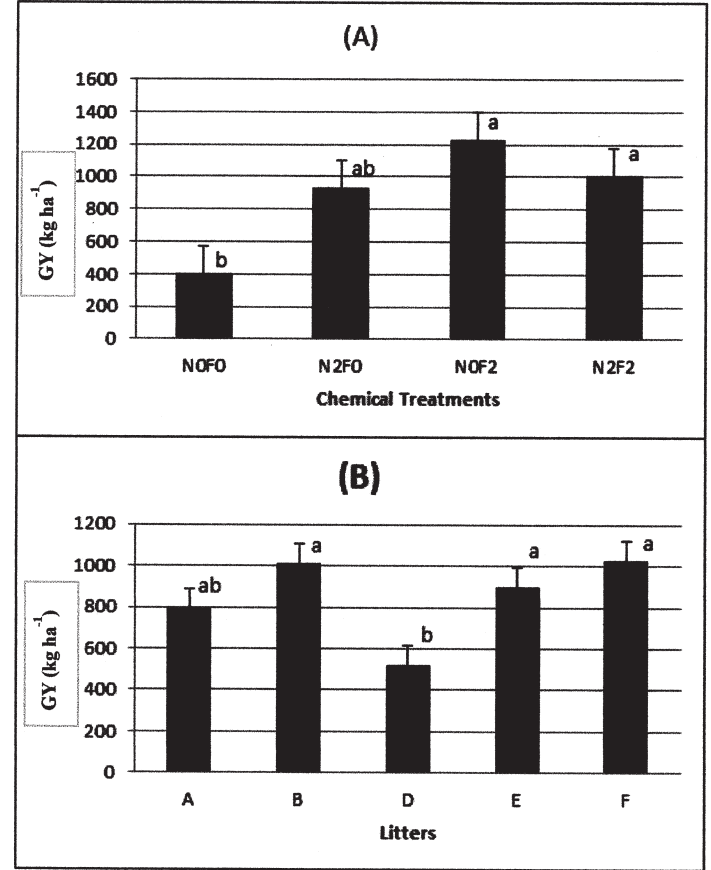

Fig. 6. Grain yields of maize as affected by the "fertilizer $\times$ insecticide" interaction (A) and litter types (B)

Results at each sampling period are means from 3 replicates plots per treatment. GY=Grain yield; NOF0=no nitrogen and fipronil; N2F0=only nitrogen; N0F2=only fipronil; N2F2=combination of nitrogen and fipronil; $\mathrm{A}=$ Andropogon gayanus; $\mathrm{B}=$ Casuarina equisetifolia; $\mathrm{D}=$ Control; $\mathrm{E}=$ Pennisetum glaucum; $\mathrm{F}=$ Faidherbia albida
The number of ears per plant (NEP) and the weight of 1000 grains (WTG) were significantly different at 1\% level in the fertilizer $\times$ insecticide combinations, while the significance of the number of grains per ear (NGE) was observed in the litter type factor (Table 1). The unfertilized treatment without insecticide had a significantly lower NEP $(\mathrm{NEP}=2)$ compared to the average $(\mathrm{NEP}=5)$ of other treatments. However, no significant difference was observed between the litter treatments in terms of NEP. For the weight of 1000-grains (WTG), the only application of urea led to a significantly higher value of $155 \mathrm{~g}$ compared to the control (119g). With only fipronil or with the combination of urea and fipronil, an average value of $143 \mathrm{~g}$ WTG was obtained. Concerning the number of grains per ear of maize, we observed three homogenous groups in the litter factor. One group included $F$. albida and $C$. equisetifolia with a similar NGE of 273, significantly higher than that of the control (178). The group including $P$. glaucum and $A$. gayanus litters had an intermediate impact with a NEG of 201, not significantly different with that of the control or with the group of $F$. albida and $C$. equisetifolia.

The statistical analysis revealed a significance of the fertilizer $\times$ insecticide interaction and litter factor (Table 1) for the grain yields (GY). As shown in Fig. 6A, the only application of fipronil or the combination of urea and fipronil gave significantly higher grain yields (1221 and $1000 \mathrm{~kg} \mathrm{ha}^{-1}$, respectively) in comparison with that of the control (without urea and fipronil) with $397.7 \mathrm{~kg} \mathrm{ha}^{-1}$. The application of only urea gave an intermediate maize pro-

Table 2. Results of the analysis of variance of the maximal quantic output of the photochemistry $\left(\phi_{\mathrm{P} 0}\right)$ and the use efficiency of the light $\left(\phi_{\text {E0 }}\right)$ between 42 to 70 DAS

\begin{tabular}{|c|c|c|c|c|c|c|c|c|}
\hline \multirow{2}{*}{ Factor level } & \multicolumn{2}{|c|}{42 DAS } & \multicolumn{2}{|c|}{49 DAS } & \multicolumn{2}{|c|}{63 DAS } & \multicolumn{2}{|c|}{70 DAS } \\
\hline & $\phi_{\mathrm{P} 0}$ & $\phi_{\mathrm{E} 0}$ & $\phi_{\mathrm{P} 0}$ & $\phi_{\mathrm{E} 0}$ & $\phi_{\mathrm{P} 0}$ & $\phi_{\mathrm{E} 0}$ & $\phi_{\mathrm{P} 0}$ & $\phi_{\mathrm{E} 0}$ \\
\hline NOF0 & $0.71^{\mathrm{a}}$ & $0.27^{\mathrm{a}}$ & $0.73^{\mathrm{b}}$ & $0.31^{\mathrm{b}}$ & $0.73^{\mathrm{a}}$ & $0.33^{\mathrm{b}}$ & $0.73^{\mathrm{a}}$ & $0.34^{\mathrm{a}}$ \\
\hline $\mathrm{N} 2 \mathrm{~F} 0$ & $0.73^{\mathrm{a}}$ & $0.35^{\mathrm{a}}$ & $0.77^{\mathrm{a}}$ & $0.42^{\mathrm{a}}$ & $0.75^{\mathrm{a}}$ & $0.41^{\mathrm{a}}$ & $0.73^{\mathrm{a}}$ & $0.37^{\mathrm{a}}$ \\
\hline NOF2 & $073^{\mathrm{a}}$ & $0.33^{\mathrm{a}}$ & $0.75^{\mathrm{ab}}$ & $0.36^{\mathrm{ab}}$ & $0.75^{\mathrm{a}}$ & $0.39^{\mathrm{a}}$ & $0.74^{\mathrm{a}}$ & $0.37 \mathrm{a}$ \\
\hline $\mathrm{N} 2 \mathrm{~F} 2$ & $0.75^{\mathrm{a}}$ & $0.38^{\mathrm{a}}$ & $0.77^{\mathrm{a}}$ & $0.41^{\mathrm{a}}$ & $0.76^{\mathrm{a}}$ & $0.40^{\mathrm{a}}$ & $0.75^{\mathrm{a}}$ & $0.40^{\mathrm{a}}$ \\
\hline $\begin{array}{l}\text { fertilizer } \times \text { insecticide" effect } \\
(\mathrm{F}-\text {-value })\end{array}$ & ns & ns & $*$ & $* *$ & ns & $*$ & ns & ns \\
\hline A & $0.72^{\mathrm{b}}$ & $0.32^{\mathrm{b}}$ & $0.75^{\mathrm{a}}$ & $0.36^{\mathrm{a}}$ & $0.75^{\mathrm{a}}$ & $0.38^{\mathrm{a}}$ & $0.75^{\mathrm{a}}$ & $0.40^{\mathrm{a}}$ \\
\hline B & $0.72^{\mathrm{b}}$ & $0.32^{\mathrm{b}}$ & $0.77^{\mathrm{a}}$ & $0.40^{\mathrm{a}}$ & $0.75^{\mathrm{a}}$ & $0.40^{\mathrm{a}}$ & $0.74^{\mathrm{a}}$ & $0.36^{\mathrm{a}}$ \\
\hline $\mathrm{D}$ & $0.71^{\mathrm{b}}$ & $0.30^{\mathrm{b}}$ & $0.75^{\mathrm{a}}$ & $0.38^{\mathrm{a}}$ & $0.74^{\mathrm{a}}$ & $038^{\mathrm{a}}$ & $0.76^{\mathrm{a}}$ & $0.39^{\mathrm{a}}$ \\
\hline $\mathrm{E}$ & $0.72^{\mathrm{b}}$ & $0.34^{\mathrm{ab}}$ & $0.76^{\mathrm{a}}$ & $0.37^{\mathrm{a}}$ & $0.74^{\mathrm{a}}$ & $0.37^{\mathrm{a}}$ & $0.73^{\mathrm{a}}$ & $0.36^{\mathrm{a}}$ \\
\hline $\mathrm{F}$ & $0.76^{\mathrm{a}}$ & $0.38^{\mathrm{a}}$ & $0.75^{\mathrm{a}}$ & $0.38^{\mathrm{a}}$ & $0.75^{\mathrm{a}}$ & $0.39^{\mathrm{a}}$ & $0.73^{\mathrm{a}}$ & $0.35^{\mathrm{a}}$ \\
\hline « litter » effect & $*$ & $* *$ & $\mathrm{~ns}$ & $\mathrm{~ns}$ & ns & ns & ns & ns \\
\hline $\begin{array}{l}\text { "litter } \times \text { fertilizer } \times \text { insecticide" } \\
\text { interaction: F-value }\end{array}$ & ns & ns & ns & ns & ns & ns & $\mathrm{ns}$ & ns \\
\hline C.V.1 (\%) & 7.4 & 34.2 & 3.6 & 17.3 & 4.3 & 16.6 & 5.5 & 21 \\
\hline C.V.2 (\%) & 5 & 13.6 & 3 & 12.2 & 3.7 & 10.6 & 4.4 & 13.3 \\
\hline
\end{tabular}

$*$ and $* *=$ significant at $1 \%$ and $5 \%$, respectively; ns=non-significant at 5\%. For each column, the reported averages with the same letters by factor are statistically identical at 5\%. N0F0=no nitrogen and fipronil; N2F0=only nitrogen; N0F2=only fipronil; $\mathrm{N} 2 \mathrm{~F} 2=$ combination of nitrogen and fipronil; $\mathrm{A}=$ Andropogon gayanus; $\mathrm{B}=$ Casuarina equisetifolia; $\mathrm{D}=\mathrm{Control} ; \mathrm{E}=$ Pennisetum glaucum; $\mathrm{F}=$ Faidherbia albida; C.V.1=coefficient of variation of the factor "fertilizer x insecticide" combination; C.V.2=coefficient of variation of the "litter" factor 
duction of $928.7 \mathrm{~kg} \mathrm{ha}^{-1}$. The Figure $6 \mathrm{~B}$ shows the effect of the litter factor on grain yields. Grain yields triggered by the application of $F$. albida, $C$. equisetifolia, and $P$. glaucum litters were not significantly different from one another, but were significantly higher than the control's yields (519 $\mathrm{kg} \mathrm{ha}^{-1}$ ). With $795 \mathrm{~kg} \mathrm{ha}^{-1}$ grain yield, the A. gayanus litter showed an intermediate effect between these two groups (the control and the other litters). In the end, F. albida, C. equisetifolia and P. glaucum litters increased maize productivity in grains by $94.3 \%$ on average, while the A. gayanus only improved it by $53 \%$ compared to the control without litter.

\section{The photochemical activity}

As shown in Table 2, the analysis of variance didn't reveal a significant effect of the "litter $\times$ fertilizer $\times$ insecticide" interaction on the quantification parameters of the photochemical activity: maximal quantic output of the photochemistry $\left(\phi_{\mathrm{P} 0}\right)$, and light use efficiency $\left(\phi_{\mathrm{E} 0}\right)$. However, considering only the "fertilizer $\times$ insecticide" combination, a significant effect was obtained at $49^{\text {th }}$ DAS. The two nitrogenized treatments, with and without insecticide, had a better quantic output (0.77), significantly higher than that of the control without fertilizer and insecticide (0.73). The treatment with only insecticide (fipronil) application gave an intermediate value of quantic output (0.75). At the $63^{\text {th }}$ DAS, the light use efficiency in the nitrogenized and/or insecticide applied treatments was significantly higher (0.41) than that of the control (0.31). Considering the "litter" factor, there was a significant effect on $\phi_{\mathrm{P} 0}$ and $\phi_{\mathrm{E} 0}$ only on the $42^{\text {th }}$ DAS. At this period, it appeared that $F$. albida litters gave a significantly higher $\phi_{\mathrm{P} 0}(0.76)$ than that of the other litter types, which did not differ from the control (0.71). Similarly, the same litters of $F$. albida significantly led to a higher $\phi_{\mathrm{E} 0}(0.38)$ in comparison to the other litter treatments.

\section{DISCUSSION}

Sandy soils are widely distributed in the tropics where they occupy most of the arid and semi-arid areas. These soils are characterised by a low level of soil organic carbon, a low cation exchange capacity (CEC), a high risk of nutrient leaching, low structural stability, and high sensitivity to erosion. Both chemical fertilizer and physical stability are weak in these soils (Pieri, 1992; Sanchez and Logan, 1992). Due to these facts, the influence of organic matter on the properties of these soils, on their potential of productivity, and on the sustainability of agricultural systems is thus fundamental (Pieri, 1992; Feller, 1995b). Soil organic matter (SOM) in fine and medium fractions influences the capacity of a soil to store and exchange nutrients. In this respect, Hien (2004) indicated that the application of manure along with a $\mathrm{N}$ fertilizer is favourable for preferential storage of $\mathrm{C}$ in the fine fractions. In parallel, the role of plant debris in the biogeochemical functioning of sandy soils appears fundamental. This is especially true for $\mathrm{N}$, as in sandy soils $\mathrm{N}$ initial reserve and storage potential are low and SOM turnover is rapid
(Blondel, 1971; Ruiz et al., 1995). From an agronomic point of view, there is a need to favour agricultural practices that allow an important and constant restitution of plant or animal debris (Ganry, 1991; Feller, 1995a; Manlay et al., 2002). To this respect, litters of locally available species in combination with $\mathrm{N}$ fertilizer and insecticide were tested on maize growth and production, in a tropical sandy soil of Central Senegal (Thies). Extra irrigation was carried out for satisfactory hydrous conditions, important for the nitrogen dynamic as reported by Ganry et al. (1995)

Our results on photochemical activity $\left(\phi_{\mathrm{P} 0}\right.$ and $\left.\phi_{\mathrm{E} 0}\right)$ distinguished the treatments with inorganic $\mathrm{N}$ application and $F$. albida litter (higher activity) from the other treatments, which showed lower activity. The good photochemical activity observed in these treatments could be related to higher chlorophyll content and in complex pigment-proteins, respectively involved in the absorption of photons, and in the trapping and transfer of energy towards the reaction centres. Guèye (2002) reported the possibility of using the chlorophyll content as an indicator of tolerance to the hydrous constraint. According to this author, the effects of mineral deficiencies (with nitrogen in particular) are similar to those induced by the hydrous deficit. Other authors (Jung 1967; Louppe et al., 1996) have reported the important release of nutrient elements, nitrogen in particular, from $F$. albida litter during its decay. The release of nitrogen, slow in dry season (11\%), would be more important in the rainy season (55\%) as reported by Diallo (1999) and would have a similar effect as that of the urea contribution in this present study. Hence, the good photochemical activity from these two treatments in the middle of the growing stage could be linked to $\mathrm{N}$ contribution, and the absence of a significant difference at the end could result from a decrease of the photosynthetic activity due to plant senescence.

Considering the different growth parameters and yield components, the application effect of $F$. albida and C. equisetifolia litters was most positive and was comparable to that of nitrogenized treatments. The influence of litter quality on decomposition and impact on soil quality has been a subject of study and a significant amount of literature has come out in the last two decades. In terms of agronomical aspects, litter quality refers to the relative ease of decomposition by decomposing organisms and associated mineralization of nutrients (Paustian et al., 1997). On the other hand, retardation in the rate of decomposition favors more resident period for the input $\mathrm{C}$ and this environmental aspect of litter quality is gaining importance in the soil $\mathrm{C}$ sequestration efforts to minimize the $\mathrm{CO}_{2}$ build up in the atmosphere (Janzen, 2006). Although we did not follow their decomposition rate, litters were applied 2 months and half before the starting of the experiment, to ensure a good decomposition. $F$. albida followed by $C$. equisetifolia results in lower $\mathrm{C} / \mathrm{N}$ ratios of 21.4 and 35, respectively, in comparison with $P$. glaucum and $A$. gayanus with 50 and $51 \mathrm{C} / \mathrm{N}$ ratios, respectively. Litters of $F$. albida and $C$. equisetifolia with desirable $\mathrm{C} / \mathrm{N}$ ratios contributed to significant $\mathrm{N}$ release for use by subsequent maize crop. These litters 
have the particularity of having good nitrogen content according to the results of researches carried out by Olivier et al. (1990) and Louppe et al. (1996). The output in maize grain yields the following application of these litters was $93.4 \%$ higher than that of the control. This output improvement is widely beyond that reported by Pieri (1986) who obtained 10\% maize grain improvement when $10 \mathrm{t} \mathrm{ha}^{-1}$ of sorghum litter was applied and a $22 \%$ gain over the control when the litter was combined with $60 \mathrm{~kg} \mathrm{~N} \mathrm{ha}{ }^{-1}$. Litters with high $\mathrm{C} / \mathrm{N}$ ratios may lead to $\mathrm{N}$ immobilization, which needs to be overcome by additional N. Elsewhere in the tropics; Grant (1981) stated that when old fallow soils in Zimbabwe are tilled for cropping, the problem of low fertility of sandy soils is compounded by competition for available nutrients with soil micro-organisms that proliferate. As micro-organisms need nitrogen to develop, Delville (1996) stated that a straw contribution should be, if possible, accompanied with a mineral nitrogen contribution to counter the depressive effect.

On the other hand, litter quality controlled by the content of polysaccharides, lignin/tannin, and polyphenols, has an impact on the decomposition rate. The polysaccharides are good substrates for microbes and hence degrade rapidly in soils. The presence of species such as lignin/tannin tend to slow down the decomposition process of litter considerably and are reported to be the most recalcitrant materials among the naturally occurring organic compounds (Hammel, 1997). Several studies have mentioned the negative effect of polyphenols on the N mineralization process (Palm and Sanchez, 1991). Diallo et al. (2005) investigated the effect of 5 leaf litters of different qualities on soil nitrogen mineralization patterns during a mid-term field experiment (12 months), and reported that any relationship could be between litter quality ( $\mathrm{N}$ content, cellulose, hemicellulose, and lignin) and $\mathrm{N}$ mineralization. During a laboratory incubation experiment, Sall et al. (2003) compared the effect of $A$. gayanus, $C$. equisetifolia, $F$. albida on $\mathrm{C}$ and $\mathrm{N}$ dynamics in the presence or not of inorganic N. They found a similar immobilization in soil amended with $A$. gayanus, $C$. equisetifolia, despite the fact that these materials have different $\mathrm{C} / \mathrm{N}$ ratios, and related this situation to the abundant polyphenol content in $C$. equisetifolia litters. The addition of inorganic $\mathrm{N}$ modified the patterns of $\mathrm{CO}_{2}-\mathrm{C}$ respiration and net $\mathrm{N}$ immobilization, and the magnitude of these modifications varied according to the litter quality. The inclusion of inorganic fertilizer and insecticide as part of a mixture in our experiment resulted in improved grains, total above-ground biomass yields and 1000-grain mass. The supply of N may have shortened the period of immobilization, and may have stimulated nutrient mineralization at a time when nutrients were required by plants; while the insecticide application may have enhanced the wealth of the plant for better physiological response and nutrient uptake dynamic.

In conclusion, productivity of ecosystems characterized by sandy soils is generally low because of erratic rainfall and poor nutrient availability. It appears from this study that sustainable management of locally available plant residues integrating the use of inorganic $\mathrm{N}$ and insecticide, can greatly contribute to elevated soil quality for subsequent yield increase. In this study, litters of Faidherbia albida (Chev.) were shown to improve the quantic maximal output of the photochemistry $\left(\phi_{\mathrm{P} 0}\right)$ and use efficiency of the energy ( $\phi_{\mathrm{E} 0}$ ) by 6 and $26 \%$, respectively. Similarly, the nitrogenized treatments increased the activity by 5 and $40 \%$. Together with that of Casuarina equisetifolia (Forssk), litters of Faidherbia albida (Chev.) lead to a significant increase in the number of grains per ear. Therefore, it appears that the inclusion of inorganic $\mathrm{N}$ would be more beneficial with higher $\mathrm{C} / \mathrm{N}$ ratio litters such as $P$. glaucum and $A$. gayanus to maximize their effect.

\section{ACKNOWLEDGMENTS}

The authors are grateful to the IRD (Institut de Recherche pour le Développement, France) for founding part of the present study through the "Interactions Biologiques dans les Sols des Systèmes Anthropisés Tropicaux (IBIS) » Programme. These thanks also go to M. Papa Mamadou Ndiaye, technician at the CERAAS and Ms Larissa Popp.

\section{REFERENCES}

Aggangan, R. T., A. M. O'Connell, J. F. McGrath and B. Dell 1999 The effect of Eucalyptus globulus Labill. leaf litter on $\mathrm{C}$ and $\mathrm{N}$ mineralization in soils from pasture and native forest. Soil Biol. Biochem., 31: 1481-1487

Anon 1997 The maize field handbook, ed. by K. W. S. Huntseeds Ldt, Woolaston, UK

Badiane, A. N. 1993 Le statut organique d'un sol sableux de la zone Centre-Nord du Sénégal (PhD thesis). Institut National polytechnique de Lorraine (INPL), Nancy (in French with English summary)

Blondel, D. 1971 Contribution à la connaissance de la dynamique de l'azote minéral: en sol sableux au Senegal. Agron. Trop. 26: 1303-1333 (in French with English summary)

Broutin, C. and K. Sokona 1999 Innovations pour la promotion des céréales locales: Reconquérir le marché urbain. Série Etudes et Recherches 206-207, Union Européenne/République du Sénégal/PPCL, ed. by GRET/ENDA-GRAF. Dakar, Senegal, p. 147 (in French)

Caravaca. F., C. Garcia, M.T. Hernandez and A. Roldan 2002 Aggregates stability changes after organic amendment and mycorrhizal inoculation in the afforestation of a semiarid site with Pinus halepensis. Appl. Soil Ecol., 19: 199-208

Daps (Direction de l'analyse et de la prévision des statistiques) 1990 Enquêtes sur les priorités au Sénégal. Réseau de développement urbain et lutte contre la pauvreté, Daps/MEF, p. 108 (in French)

Davis-Carter, J. C. 1989 Influence of spatial variability of soil physical and chemical properties on the rooting patterns of soil millet and sorghum (PhD thesis). Texas A\&M University, College Station, (Diss. Abstr. 9007465), USA

Delville, P. L. 1996 Gérer la fertilité des terres dans les pays du Sahel, Coll. Le point sur, DUMAS, Saint- Etienne, France, p 397 (in French)

Diallo, M. D., A. Guisse, A. Badiane-Niane, S. Sall and J. L. Chotte 2005 In situ effect of some tropical litters on $\mathrm{N}$ mineralization. Arid land Res. Manag., 19: 1-9

Diallo, M. D. 1999 Etude de la décomposition des litières d'espèces sahélienne et de leur influence sur la nitrification in situ (Master thesis). Cheikh Anta Diop University, Dakar, Sénégal (in French with English summary) 
Feller, C. 1995a La matière organique dans les sols tropicaux à argile 1:1. Recherche des compartiments fonctionnels. Une approche granulométrique. Collection TDM, col. 144, ORSTOM, Paris

Feller, C. 1995b La matière organique du sol: un indicateur de la fertilité. Application aux zones sahélienne et soudanienne. Agric. Develop., 8: 35-41

Ganry, F., L. Ruiz, V. Waneukem, P. Siband and R. Oliver 1995 Matière organique et azote, facteurs de production: recherche d'indicateurs de fertilité azotée des terres. Agric. Develop., 5: 38-46 (in French with English summary)

Ganry, F. 1991 Valorisation des résultats de récolte a la ferme et maintien de la fertilité. Cas du sud Senegal. In Savanes d'Afrique, Terres fertiles?, ed. by CIRAD, Montpellier, pp. 317331 (in French with English summary)

Grant, P. M. 1981 The fertilization of sandy soils in peasant agriculture. Zimb. Agric. J., 78: 169-175

Guèye, M. 2002 Réponses morpho-physiologiques au déficit hydrique du sésame (Sesamum indicum L.) au jeune âge (Master thesis). Cheikh Anta Diop University, Dakar, Sénégal (in French with English summary)

Hammel, K. E. 1997 Fungal degradation of lignin. In Driven by nature, ed. Y G. Cadisch, K. E. Giller. CAB International, Oxon, UK, pp. 33-45

Hamon, R. 1968 Modalités pratiques de fabrication de fumier, Rendements obtenus, Applications possibles en milieu rural sénégalais, 1790-1802. In Colloque sur la fertilité des sols tropicaux, Tome II, 19-25 novembre 1967. Tananarive, Madagascar, pp. 1790-1802 (in French)

Hamon, R. 1972 Lhabitat des animaux et la production d'un fumier de qualité en zone tropicale sèche (bilan de trois année d'études). Agron.Trop., 27: 592-607 (in French)

Hien, E. 2004 Dynamique du carbone dans un Acrisol ferrique du Centre Ouest Burkina: Influence des pratiques culturales sur le stock et la qualité de la matière organique. Thèse de doctorat de l'école Nationale Supérieure d'Agronomie de Montpellier, $\mathrm{p}$. 138 (In French with English summary)

IAC (InterAcademy Council) 2004 Realizing the promise and potential of African Agriculture. Amsterdam

Janzen, H. H. 2006 The soil carbon dilemma: shall we hoard it or use it. Soil Biol. Biochem., 38: 419-424

Jung, G. 1967 Influence de l'Acacia albida Del. sur la biologie des sols « diors », ORSTOM, Dakar, Sénégal, p. 66 (in French)

Louppe, D., B. Ndour and A. N. S. Samba 1996 Influence de Faidherbia albida sur l'arachide et le mil au Sénégal. Méthodologie de mesure et estimations des effets d'arbres émondés avec ou sans parcage d'animaux. In Les parcs à Faidherbia, Cahier Scientifique 12, ed. by R. Peltier, CIRADForêt, Montpellier, France, pp. 123-139 (in French with English summary)

Madeley, J. 2002 Food for all: The need for a new agriculture, p. 34

Manlay, R. J., D. Masse, J. L. Chotte, C. Feller, M. Kaire, J. Fardoux and R. Pontanier 2002 Carbon, nitrogen and phosphorus allocation in agro-ecosystems of West African savanna. II. The soil component under semi-permenant cultivation. Agric. Ecosyst. Environ., 88: 233-248

MEPN (Ministère de l'Environnement et de la Protection de la Nature) 1997 Plan Régional d'Action pour l'environnement : région de Thiès, Dakar, Sénégal, p. 23 (in French)

Murwira, H. K. and H. Jirchmann 1993 Carbon and nitrogen mineralization of cattle manures subjected to different treatments in Zimbawean and Swedish soils. In Soil Organic Matter Dynamics and Sustainability of Tropical Agriculture, ed. by K Mulongoy, R. Merckx, A Wiley Sayce Co-Publication IITA/K.U., Leuven, pp. 189-198

Ndiaye, W. 1994 Etude des interactions génotypes-milieu sur la tolérance au stress hydrique du maïs (Zea mays L.) (Mémoire d'ingénieur agronome). Ecole Nationale Supérieure d'Agriculture, Thiès, Sénégal (in French).

Olivier, R., D. Depommier and E. Janodet 1990 Influence de Faidherbia albida sur le sol et le sorgho. Observations dans le parc de Watinoma au Burkina Faso. In Les parcs à Faidherbia, Cahier Scientifique 12, ed. by R. Peltier, CIRADForêt, Montpellier, France, pp. 141-152 (in French with English summary)

Palm, C. A. and P. A. Sanchez 1991 Nitrogen release from leaves of some tropical legumes as affected by their lignin and polyphenol contents. Soil Biol. Biochem., 23: 83-88

Paustian, K., G. I. Agren and E. Bosatta 1997 Modelling litter quality effects on decomposition and soil organic matter dynamics. In Driven by nature, ed. by G. Cadisch, K. E. Giller, CAB International, Oxon, UK, pp. 313-335

Piéri, C. 1986 Food crop fertilizing and soil fertility in in sub-Saharan small-holder farming. Agron. Trop., 10: 88-97

Pieri, C. 1992 Fertility of soils: a future for farming in the West African Savannah. Springer Series in Physical Environment, Springer-Verlag, Berlin, p. 238

Quintana, J. O., J. Pereira, D. R. Bouldin and D. J. Lathwell 1988 Screening legume green manure as nitrogen sources to succeeding non-legume crops. Plant Soil, 111: 81-85

Roldan, A., J. Albaladejo and J. B. Thornes 1996 Aggregate stability changes in a semiarid soil after treatment with different amendments. Arid Soil Res. Rehab., 10: 139-148

Ruiz, L., F. Ganry, V. Waneukem, P. Siband and R. Olivier 1995 Recherche d'indicateurs de fertilité azote des terres. Agric. Develop., 5: 38-46 (in French with English summary)

Sall, S. N., D. Masse, F. Bernhard-Reversat, A. Guisse and J. L. Chotte 2003 Microbial activities during the early stage of laboratory decomposition of tropical leaf litters: the effect of interactions between litter quality and exogenous inorganic nitrogen. Biol. Fert. Soils, 39: 103-111

Sanchez, P. A. and T. J. Logan 1992 Myths and science about the chemistry and fertility of soils in the tropics. In Myths and Science of Soils of the Tropics, ed. by R. Lal and P. A. Sanchez , SSSA Spec. Publ. 29. ASA, SSSA, Madison, WI, pp. 35-46

Scoones, I. C. 1990 Livestock Populations and the Household economy: Case Study from Southern Zimbabwe (PhD Thesis). University of London, UK 